\title{
Sian lietelannan käyttö viljojen lannoitukseen
}

Petri Kapuinen ja Sanna Tyynelä

Maa- ja elintarviketalouden tutkimuskeskus, maatalousteknologian tutkimus, Vakolantie 55, 03400 VIHTI, petri.kapuinen@mtt.fi

\section{Johdanto}

Sian lietelannan levitys keväällä on ongelma Suomen lyhyessä kasvukaudessa (Kemppainen 1989, Steineck ym. 1991). Syyslevityksen lannoitusvaikutusta on kuitenkin vaikea ennustaa. Syksyllä levitetyn lannan ravinteiden yleensä huono hyväksikäyttö johtaa ympäristöhaittoihin. Tässä mielessä parempi kevätlevitys saattaa kuitenkin johtaa märän pohjamaan tiivistymiseen pyrittäessä kasvukauden mahdollisimman tehokkaaseen hyödyntämiseen (Alakukku 1997). Tiivistymiselle alttiit maalajit ovat vallitsevia juuri merkittävimmillä sikatalousalueilla (Kapuinen 1994).

Ongelmaa on viime vuosina pyritty ratkaisemaan levittämällä liete kasvustoon (Hoffman ja Hege 1985, Pedersen ja Østergaard 1991, Rodhe ja Salomon 1992a, 1992b, Kapuinen 1996). Menetelmällä on saavutettu vastaavia satoja kuin levittämällä lietelanta pinnalle ja multaamalla se tunnin kuluessa levityksestä (Kapuinen 1997, Kapuinen, julkaisematon aineisto). Etuna on, että kylvötöiden eteneminen ei häiriinny, lannanlevityksen suuri työnmenekki siirtyy myöhempään vähemmän kiireiseen ajanjaksoon ja tiivistymiselle altis märkä pohjamaa on ehtinyt kuivua. Menetelmällä ei kuitenkaan saavuteta vastaavia satoja kuin väkilannoitteella rinnastettaessa lietteen liukoinen typpi väkilannoitteen typpeen. Osasyynä tähän on typen tappiot ammoniakkina (Mattila 2001), mutta myös ravinteiden jääminen kasvien saannin kannalta epäedulliseen paikkaan, muokkauskerroksen yläosaan. Typen tappioita ei voida korvata väkilannoitetyppitäydennyksellä maatalouden ympäristötukiohjelman puitteissa (MMM 1995a, 1995b, 1996, 1997, 2000). Lämpötila ja tuulen nopeus vaikuttavat voimakkaasti ammoniakkitappioiden suuruuteen, mikä tekee kasvustoon levityksen lannoitusvaikutuksesta vaikeasti ennustettavan. Kasvustoon levittäminen aiheuttaa lisäksi konflikteja muun maaseutuyhteisön kanssa, koska hajuhaitta jatkuu pitkään toukokuun alusta kesäkuun loppuun ajoittuen yhteen kesälomakauden kanssa.

Ammoniakkitappioiden ja hajuhaittojen poistamiseksi ja ravinteiden hyväksikäytön parantamiseksi lietelannan levittämiseen kehitettiin sijoitusmenetelmä, jossa lietelanta sijoitetaan ennen kylvöä tai kylvön yhteydessä joka toiseen kylvöriviväliin, mikä on todettu hyväksi menettelyksi väkilannoitteen levityksessä (Kara ym. 1970, Huhtapalo 1982). Menetelmässä pyritään levittämään lietelantaa vuoden keskimääräistä fosforintarvetta vastaava määrä ja täydentämään typpilannoitusta väkilannoitetypellä. Kehitettyjen menetelmien arvioimiseksi tässä tutkimuksessa selvitetään sijoitusmenetelmien vaikutukset sadon määrään ja laatuun suhteessa lietelannan pintalevitykseen, lietelannan käytön vaikutukset suhteessa väkilannoitukseen sekä lietekaluston tallauksen vaikutukset sadon määrään ja laatuun.

\section{Aineisto ja menetelmät}

Satovaikutusten selvittämiseksi tutkimuksessa verrataan kylvöön yhdistettyä lietelannan sijoitusta ja täydennyslannoitusta väkilannoitetypellä, kylvöstä ja täydennyslannoituksesta erilliseen lietelannan sijoitukseen ja perinteiseen pintalevitykseen. Tutkimus toteutettiin Vihdissä hiesusavimaalla käyttäen koekasvina Inari-ohraa. Tähän mennessä aineistoa on kerätty vuosilta 2000 ja 2001 . Koejäseninä ovat:

B1) kylvöön yhdistetty lietelannan sijoitus ja täydennyslannoitus,

B2) erillinen lietelannan sijoitus ja täydennyslannoitus kylvön yhteydessä,

B3) lietelannan letkulevitys pintaan, multaus tunnin kuluttua levityksestä ja täydennyslannoitus kylvön yhteydessä multauksen jälkeen,

B4) kylvöön yhdistetty lietelannan sijoitus ("luomuvaihtoehto", vuosi 2001) ja

B5) yhdistetty sijoituslannoitus väkilannoitteella ja kylvö (tallaustappiokäsittely).

Käsittelyissä liukoisen typen annostavoite oli $100 \mathrm{~kg} / \mathrm{ha}$. Koejäsenissä 1,2 ja 3 se kertyi lietelannan ja väkilannoitteen typestä, koejäsenessä 4 pelkästä lietelannan typestä ja koejäsenessä 5 pelkästä väkilannoitteen typestä. Kokeeseen liittyi typpilannoitusportaat: 0(A1), 50(A2), 75(A3), 100(A4) ja 125(A5) kg N/ha. Koemuoto oli satunnaistetut lohkot. Ensin arvottiin käsittelyt A ja B lohkoihin ja tämän jälkeen niiden sisälle käsittelyt A1-A5 ja B1-B5. Käsittelyistä määritettiin normisato, puintikosteus, raakavalkuaispitoisuus, hehtolitrapaino, tuhannen jyvän paino ja rikkapitoisuudet. Tulokset analysoitiin varianssianalyysilla Tukeyn monivertailumenetelmää käyttäen. 


\section{Tulokset ja tulosten tarkastelu}

Typpilannoitus kasvatti satoa, raakavalkuaispitoisuutta ja -satoa sekä tuhannen jyvän painoa aina 100 $\mathrm{kg} \mathrm{N} / \mathrm{ha}$ tasolle asti. Lannoittamattomuus lisäsi surkastuneiden (1-2 mm) ja vihreiden jyvien määrää suhteessa pieneenkin lannoitukseen (taulukko 1).

Lietevaunun tallaus (A4 versus B5) ei vuonna 2000 vaikuttanut tilastollisesti merkitsevästi ohrasadon määrään tai sen laatuun (taulukko 1). Vuonna 2001:kin ainoa vaikutus, sekin vain suuntaaantava, oli hehtolitrapainon aleneminen $1,7 \mathrm{~kg}$. Mitattu tallaustappio oli vuonna 2001 suurempi kuin 2000, mikä todennäköisesti johtui siitä, että muokkauskerroksen $(26,3 \%$ vs $19,4 \%$ ) ja pohjamaan (32,1-36,4\% vs 27,5-29,5\%) kosteuspitoisuus vuonna 2001 oli suurempi kuin vuonna 2000.

Lietelannan käytöllä ohran lannoitteena oli vuosina 2000 ja 2001 tilastollisesti merkitseviä vaikutuksia ohran normisatoon, sekä raakavalkuaispitoisuuteen ja -satoon, vuonna 2000 myös puintikosteuteen (taulukko 1). Vuonna 2000 lietelannan ja väkilannoitteen kylvön yhteydessä sijoittamista (B1) lukuun ottamatta lietelannan käyttö alensi normisatoa keskimäärin $625 \mathrm{~kg} / \mathrm{ha}$ eli $12,1 \%$ verrattuna tallauskäsittelyyn (B5). Kokeeseen vuonna 2001 lisätty lietelantakäsittely (B4), jossa koko lannoitus annettiin lietelantana väkilannoitteen kanssa jaetun lannoituksen sijasta koejäsenessä B1 käytetyllä tekniikalla, tuotti vuonna $2001599 \mathrm{~kg} / \mathrm{ha}$ eli 12,2 \% suuremman sadon kuin tallauskäsittely (B5) ja $558 \mathrm{~kg} / \mathrm{ha}$ eli $11,3 \%$ suuremman normisadon kuin jaetulla lietelanta- ja väkilannoitelannoituksella lannoitetut käsittelyt (B1-B3). Sen sijaan yhdenkään vuonna 2000 mukana olleen lietelantakäsittelyn sato vuonna 2001 ei eronnut tallauskäsittelyn (B5) sadosta.

Vuonna 2000 osana lannoitusta sijoittamalla levitetty lietelanta (B1-B2) alensi ohran puintikosteutta 2,0 \%-yksikköä verrattuna tallauskäsittelyyn (B5) (taulukko 1). Sijoitusmenetelmän käyttö lietelannan levityksessä johti vuonna 2000 1,3\%-yksikköä pienempään puintikosteuteen kuin pintalevitystekniikan käyttö. Puintikosteus ei ollut kuitenkaan suurempi kuin väkilannoitteella lannoitettaessa. Lietelannan käytöllä osana lannoitusta (B1-B3) oli yleisesti suuntausta vähentää surkastuneiden määrää, mutta ainoastaan erillisen sijoitusmenetelmän (B2) käyttö johti edes suuntaaantavan eron syntymiseen tallauskäsittelyyn (B5) nähden.

Vuonna 2000 lietelannan käyttö osana lannoitusta (B1-B3) alensi ohran raakavalkuaispitoisuutta keskimäärin 0,8 \%-yksikköä (taulukko 1). Tämä yhdessä lietelannan käytön normisatoa alentavan vaikutuksen kanssa johti lietelantaa käytettäessä $88 \mathrm{~kg} / \mathrm{ha}$ eli $20 \%$ pienempään raakavalkuaissatoon. Vuonna 2001 lietelannan käyttö osana lannoitusta ei alentanut sadon raakavalkuaispitoisuutta. Sen sijaan pelkän lietelannan käyttö lannoitteena (B4) nosti tilastollisesti merkitsevästi sadon raakavalkuaispitoisuutta 1,2 \%-yksikköä verrattuna lietelannan käyttöön osana lannoitusta ja levitettynä erillisenä ajona sijoittaen (B2) tai pintaan (B3) ja suuntaa-antavasti keskimäärin 0,9 \%yksikköä pelkällä väkilannoitteella lannoitettuun käsittelyyn (B5) nähden. Normisadon ja raakavalkuaispitoisuuden yhteisvaikutuksena pelkän lietelannan käyttö lannoitteena (B4) nosti tilastollisesti merkitsevästi raakavalkuaissatoa osittain lietelannalla lannoitettujen käsittelyiden satoon nähden keskimäärin $103 \mathrm{~kg} / \mathrm{ha}$ eli $20,9 \%$ ja pelkällä väkilannoitteella lannoitettuun käsittelyyn nähden $101 \mathrm{~kg} / \mathrm{ha}$ eli $20,5 \%$. Osa raakavalkuaispitoisuuden noususta pelkällä lietelannalla lannoitettaessa johtui lietteen ennakkonäytettä suuremmasta typpipitoisuudesta, joka johti siihen, että koejäsenessä B4 liukoisen typen määräksi tuli $120 \mathrm{~kg} / \mathrm{ha}$. Väkilannoitetta käytettäessä ohran raakavalkuaispitoisuus ei kuitenkaan noussut lannoitustason noustessa $100 \mathrm{~kg}$ :sta N/ha $125 \mathrm{~kg}:$ aan N/ha, joten osa vaikutuksesta aiheutui lannan typen myöhäisestä mobilisaatiosta.

Suurimpana syynä lietelannan erilaisiin satovaikutuksiin kahden eri vuoden välillä oli sääolosuhteet. Ilman lämpötilat ja tuulennopeudet levityshetkellä olivat vuonna $200022-23{ }^{\circ} \mathrm{C}$ ja 5,7 $\mathrm{m} / \mathrm{s}$ ja vuonna $200112-13{ }^{\circ} \mathrm{C}$ ja $2,2 \mathrm{~m} / \mathrm{s}$.

\section{Johtopäätökset}

Lietevaunun aiheuttaman tallauksen ei voitu osoittaa vaikuttavan ohrasadon määrään tai laatuun negatiivisesti kokeen olosuhteissa. Lietelannan käytöllä sinällään oli vaikutusta sadon määrään ja laatuun. Vaikutukset näkyivät sadossa, puintikosteudessa, raakavalkuaispitoisuudessa ja -sadossa. Laadun alenemista ilmeni vain liian pienen typpilannoituksen takia. Sijoitustekniikalla lietteen typen lannoitusvaikutus on parhaiten ennustettavissa sääolosuhteista riippumatta, minkä tähden sijoitustekniikalla saavutetaan varmimmin hyvä ja laadukas sato. Sopivaksi typpilannoitustasoksi väkilannoitteella osoittautui $100 \mathrm{~kg} \mathrm{~N} / \mathrm{ha}$ ja lietelannalla $120 \mathrm{~kg}$ liukoista typpeä hehtaarille. Asiallisella lietelannan käytöllä voitiin tuottaa suurempi ja laadullisesti parempi sato kuin väkilannoitteella. 
Taulukko 1. Ohrasadon määrä ja laatu vuosina 2000 ja 2001 sekä varianssianalyysien tulokset Tukeyn monivertailumenetelmällä.

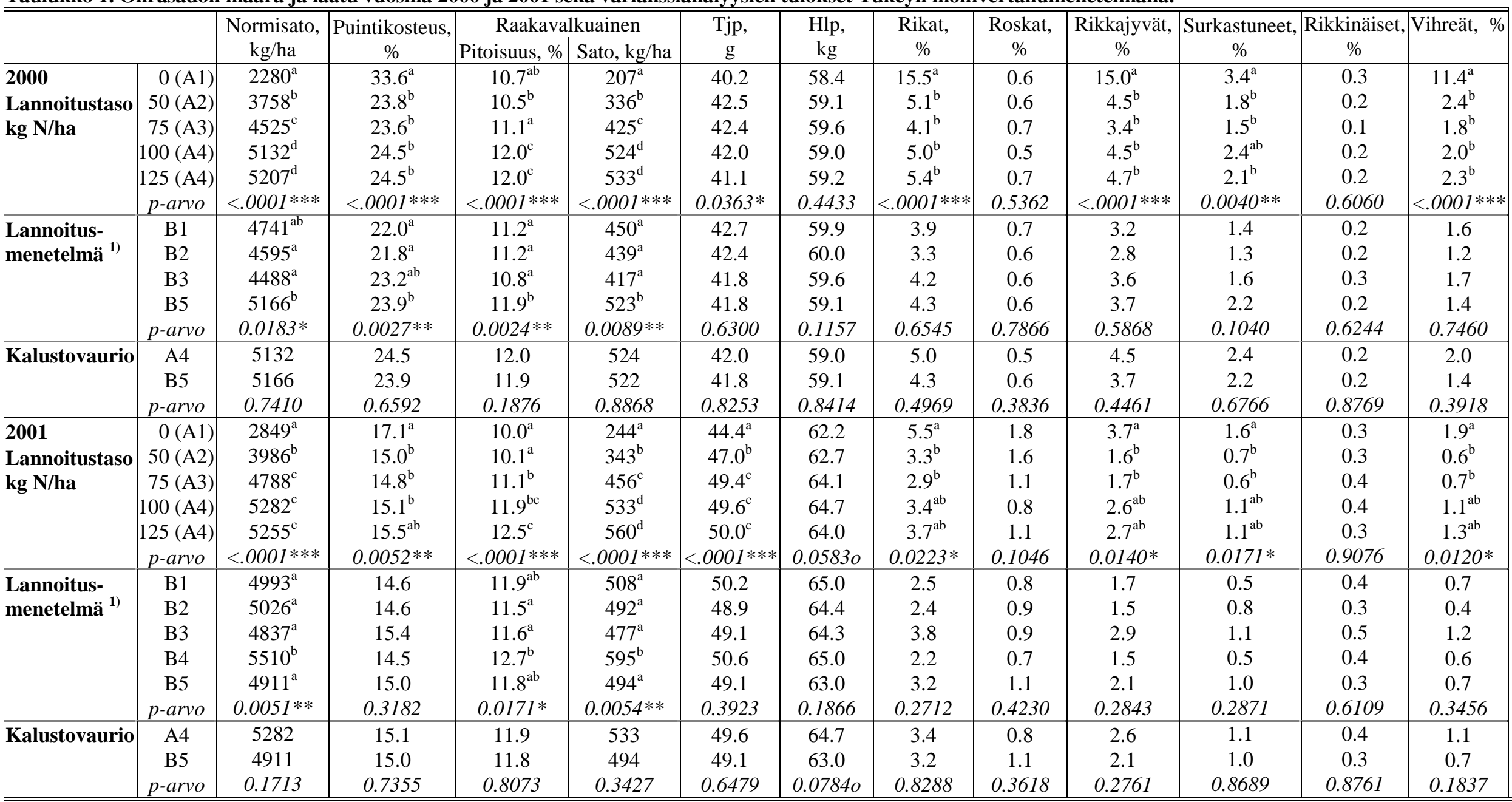

- ${ }^{1)}$ B1) Kylvöön yhdistetty lietteen sijoitus ja täydennyslannoitus. B2) Erillinen lietteen sijoitus, täydennyslannoitus kylvön yhteydessä. B3) Lietteen letkulevitys pintaan, multaus 1 h levityksestä, täydennyslannoitus kylvön yhteydessä. B4) Kylvöön yhdistetty lietteen sijoitus. B5) Yhdistetty sijoituslannoitus väkilannoitteella ja kylvö.

- ${ }^{\mathrm{a}, \mathrm{b}, \mathrm{c}, \mathrm{d}}$ Saman sarakekokonaisuuden käsittelykeskiarvot, joilla ei ole yhteistä kirjainta, eroavat tilastollisesti merkitsevästi $5 \%$ :n riskitasolla. 
Pelkän lietelannan käytöllä saavutettiin suurin sato ja sen raakavalkuaispitoisuus. Jaetullakin lannoituksella sato ja raakavalkuaissato voivat edullisena kasvukautena nousta yhtä suureksi kuin vastaavalla väkilannoitteella toteutetulla lannoituksella, mutta epäedullisena kasvukautena sato ja erityisesti raakavalkuaissato voivat jäädä selvästi pienemmäksi. Vuoden 2001 kasvukausi näytti suosivan lietelannan käyttöä ainoana lannoitteena. Epäedullisissa sääolosuhteissa lietelannan sijoituksen yhdistäminen kylvöön tuottaa varmimmin vähintään vastaavan sadon kuin vastaavalla väkilannoituksella saadaan. Pintaan levitetyn lietteen multaaminen tunnin kuluessa ei ollut riittävän nopea vastaavien satotulosten saavuttamiseksi epäedullisissa olosuhteissa.

Sijoitustekniikan käyttöä voidaan suositella sen satovaikutusten lisäksi sen positiivisilla ympäristövaikutuksilla, joita ovat ammoniakkipäästöjen ja hajuhaittojen väheneminen. Lietteen sijoittamisen yhdistäminen kylvöön edellyttää kylvötyön nopean etenemisen takia, että lietteen kuljetus ja levitys eriytetään eri kalustolle. Toisaalta se antaa hyvät mahdollisuudet keventää levityskalusto pellon rakenteen kannalta sopivalle tasolle.

\section{Kirjallisuus}

Alakukku, L. 1997. Long-term soil compaction due to high axle load traffic. Agricultural Research Centre of Finland. Institute of Crop and Soil Science. Väitöskirja. 55 p + 5 liitettä.

Hoffmann, H. \& Hege, U. 1985. Gülle - ein wertvoller Wirtschaftsdünger. Auswertungs- und Informationsdienst für Ernährung. Landwirtshaft und Forsten (AID) 149: 1-28

Huhtapalo, A. 1982. Scandinavian principles for fertilizer placement. Proceedings of 9th Conference of International Soil Tillage Research Organization (ISTRO), Yugoslavia, 21-25 June: 669-674.

Kapuinen, P. 1994. Lannan käytön taloudellisuus ja lannan ravinteiden hyväksikäytön parantaminen. VAKOLAn tutkimusselostus 68: 1-90.

Kapuinen, P. 1996. Lannan levitys kasvustoon. Osa 2. Lietelannan levitysmahdollisuudet kasvavaan viljanoraaseen, VAKOLAn tukimusselostus 73: 1-62.

Kapuinen, P. 1997. Avuksi levitys suoraan kasvustoon - Lannan levittäjät ahtalla. Pellervo no 3b: 2831.

Kara, O., Räisänen, L. \& Palomäki, A. 1970. Rivilannoitus sekä rivi- ja kylvölannoituskoneet, VAKOLAn tiedote 11: 1-12.

Kemppainen, E. 1989. Nutrient content and fertilizer value of livestock manure with special reference to cow manure. Annales Agriculturae Fenniae. Väitöskirja. 28, 3: 163-284.

Maa- ja metsätalousministeriö (MMM). 1995a. Valtioneuvoston päätös maatalouden ympäristötuesta 760: $1-7$.

Maa- ja metsätalousministeriö (MMM). 1995b. Maatalouden ympäristötuen perustuki. Ohjelmakohtaiset tuet. Maatalouspolitiikan osasto. Yleiskirje 46: 1-11 + 4 liitettä.

Maa- ja metsätalousministeriö (MMM). 1996. Maatalouden ympäristötuen perustuki. Ohjelmakohtaiset tuet. Maatalouspolitiikan osasto. Yleiskirje 65: 1-13.

Maa- ja metsätalousministeriö (MMM). 1997. Maatalouden ympäristötuen perustuki. Ohjelmakohtaiset tuet. Maatalouspolitiikan osasto. Yleiskirje 85: 1-11 + 1 liite.

Maa- ja metsätalousministeriö (MMM). 2000. Ympäristötukiopas. 27 p.

Mattila, P. 2001. Ammonia volatilization from pig slurry applied to spring wheat with different techniques. Sustainable Handling and Utilization of Livestock Manure from Animals to Plants, NJF Seminar 320, Denmark, 16-19 January 2001. DIAS report 21: 82-88.

Pedersen, C.Å. \& Østergaard, H.S. 1991. Plantavlsarbeijdet i de landøkonomiske foreninger 1990. Gødning og kalkning. Landudvalget for planteavl.: 70-112, Århus

Rodhe, L. \& Salomon, E. 1992a. Spridning av flytgödsel i stråsäd. Jordbrukstekniska institutet. JTIrapport 139: 1-59 + 18 liitettä

Rodhe, L. \& Salomon, E. 1992b. Trials on Slurry Application Techniques for Cereal Crops. International Conference on Agricultural Engineering AgEng'92, Uppsala, June 1-4, 1992: 291-292.

Steineck, S., Djurberg, L. \& Ericsson, J. 1991. Stallgödsel. Sveriges lantbruksuniversitet. Speciella skrifter 43: 1-91 